\title{
Estimación de la incertidumbre aleatoria de la distorción sísmica de entrepiso de pórticos de concreto reforzado considerando la variabilidad del módulo elástico del concreto de Bogotá Estimation of random uncertainty of the seismic interstory drift ratio of reinforced concrete frames taking into account the variability of concrete elasticity modulus in Bogota
}

\author{
Daniel Ruiz ${ }^{1,2 *}$, María C. Borrero ${ }^{3 *}$, María León ${ }^{2 *}$, Hermes Vacca ${ }^{2 *}$ \\ *Pontificia Universidad Javeriana. COLOMBIA \\ Fecha de Recepción:22/02/2012 \\ Fecha de Aceptación:06/03/2013
}

PAG 95 - 106

\begin{abstract}
Resumen
Con el módulo de elasticidad del concreto, E, y con la geometría de los elementos estructurales los diseñadores establecen los desplazamientos en estructuras de concreto reforzado. Los autores recopilaron y analizaron estadísticamente la información de ensayos de resistencia a la compresión, f `c, con medición de E para Bogotá (más de 1500 ensayos). Posteriormente se realizó un diseño de edificaciones de 5 pisos siguiendo las especificaciones de la norma NSR-10 (AIS, Asociación Colombiana de Ingeniería Sísmica, 2010) y con dos de los espectros de la reciente microzonificación (año 2010). Con estos edificios y con 1500 números aleatorios de f c y E (basados en los análisis estadísticos de ensayos de laboratorio), se hicieron 6000 simulaciones computacionales variando $E$ y $f$ `c para determinar las deformaciones máximas de entrepiso (en \% de la altura del entrepiso) de los edificios. Se establecieron las deformaciones para análisis modales espectrales y para análisis de fuerza horizontal equivalente. De acuerdo con los resultados, las deformaciones de entrepiso serian en promedio $147 \%$ de las de diseño. Asimismo, en promedio 67 de cada 100 edificaciones de cinco pisos diseñadas en Bogotá con la NSR-10 (Norma Sismo resistente) tendrían deformaciones de entrepiso mayores a $1 \%$. Por ello se propone modificar la fórmula de estimación de E de la NSR-10 (para Bogotá) para hacer una estimación más segura y confiable de las deformaciones de entrepiso sísmicas.
\end{abstract}

Palabras Clave: Deformación de entrepiso, análisis estadístico, ensayos de laboratorio, simulaciones computacionales

\begin{abstract}
Based on the modulus of elasticity of concrete (E) and the geometry of the structural elements, the displacements of reinforced concrete structures are assessed by designers. The authors compiled and statistically analyzed the information of concrete strength tests, $f C$ with measurement of $E$ (more than 1500 tests). Afterwards, a design of 5-story buildings was done following the specifications of the NSR-10 (AIS, Asociación Colombiana de Ingeniería Sísmica, 2010) and using two of the design spectrums of the recent seismic micro-zoning of Bogota (year 2010). With these buildings and with 1500 random numbers for $f^{\prime} \mathrm{C}$ and $E$ (based on the statistic analyses of laboratory tests), 6000 computer simulations, varying $E$ and $f^{\prime} c$, was done to determine the seismic drifts (as a percentage of the interstory distance) of the buildings. Seismic drifts were determined from spectral modal analyses and equivalent horizontal force analysis. In agreement with the results, the seismic drifts would be in average $147 \%$ of the seismic design drifts. Additionally, in average, 67 of each 100 buildings of five floors designed and constructed in Bogota with the NSR-10 would have seismic drifts higher than 1\%. For that reason, the authors propose to modify the formula of the elasticity modulus included in the NSR 10 (at least for Bogota), in order to make a safer and reliable estimation of $E$ and the seismic drifts.
\end{abstract}

Keywords: Seismic drift, statistical analysis, laboratory tests, computer simulations

\section{Intoduction and general backgrounds}

The conventional design of reinforced concrete buildings developed by structural engineers is always linear, due to the stiffness estimation carried out; which is based on a failure performance for an inertial force, drawn from an absolute accelerations spectrum and from the system mass. Resistance, in turn, is assessed by means of an equivalent linear analysis, but employing inertial forces reduced by an $R$ factor, which assumes an inelastic behavior, by guessing that linear deformations are the same as the ones for nonlinear deformations provided that both are under the same loading stress level. This is the so-called "Principle of equal deformations». However, it has not been proven for all cases. Nevertheless the procedure is employed for structural design.

\footnotetext{
${ }^{1}$ Autor de correspondencia / Corresponding author:

E-mail: daniel.ruiz@javeriana.edu.co

${ }^{2}$ Grupo Estructuras y Construcción, Departamento de Ingeniería Civil, Facultad de Ingeniería, Pontificia Universidad Javeriana. Colombia

${ }^{3}$ Ingeniera Civil, Departamento de Ingeniería Civil, Facultad de Ingeniería, Pontificia Universidad Javeriana. Colombia
} 
Accordingly, the most important parameters employed by estimator engineers for reinforced concrete buildings design are: elasticity modulus $(E)$, concrete compression resistance at 28 days $\left(f^{\circ} \mathrm{C}\right)$, reinforced concrete yield strength $(F y)$, the geometry of structural elements and their loads. By simultaneously taking in to account such variables, buildings are designed in accordance with the existing regulations AIS (Asociación Colombiana de Ingeniería Sísmica), 2010.

The most significant variable for stiffness allocation, as well as for sections sizing of structural elements is the concrete elasticity modulus, resulting from concrete curve tension $\mathrm{v} / \mathrm{s}$ deformation, which tends to be a parabola rather than a straight line. In the case of Colombian regulation, the NTC4025. Norma Técnica Colombiana (ICONTEC) 2005; number represents the definition of the elasticity modulus. In spite of such nonlinearity, the modulus becomes integral and linear part of the whole stiffness matrix in any designed building. As a result, any elasticity modulus increase represents - in the same proportion - a reduction of the achieved displacements and deformation of the interstory. In the particular case of Bogotá, the elasticity modulus becomes significantly important, considering that the framed buildings design (or having dual systems) is normally controlled, so that interstory deformations do not achieve more than $1 \%$ of the interstory height. In the present research every time an interstory deformation is mentioned, it shall be understood as the ratio (percentage) existing between the displacements of two consecutive story and the interstory height.

According to reference Gallego M. y Sarria A. (2006), the elasticity modulus variation increases the uncertainty of the structural system stiffness. As per the reference Ruiz D., Vacca H. y León M (2007), for the case of Bogotá and 21MPa concrete, concrete can have an elasticity modulus varying from $7500 \mathrm{MPa}$ to $22500 \mathrm{MPa}$ at the age of 28 days. Such variation automatically causes that interstory deformations, calculated by means of numerical models, be different to the actual ones. Gallego M. y Sarria A. (2006), indicates that reliability studies have established that results from numerical models may yield some mistakes, almost 30\% higher than the actual estimation for buildings displacements (and therefore, interstory deformation). However, in the particular case of Bogotá there are few publications showing such variation (excepting Muñoz E., Ruiz D. y Prieto J., 2005 y Prieto J., Muñoz E., Ruiz D. and Ramos A., 2005); therefore this is the purpose of the present research to be presented in the following paragraphs.

\section{Variability of $f$ ' $c$ and $E$ for concrete in Bogotá}

The material properties do not have an accurate value; therefore, there is always some kind of dispersion and variability. 
Similarly, concrete manufacturing and curing processes (cylinders and structural elements) affect concrete compression strength and its elasticity modulus. It must be indicated that in the present research $92.6 \%$ of tested cylinders correspond to concrete cylinders, which curing conditions were controlled by a Test Laboratory fulfilling the standard ISO 17025 (standard for quality management systems in Test Laboratories). The remaining $7.4 \%$ corresponds to tests developed on concrete cores extracted from existing structures.

In spite of the wide variability of mechanical characteristics of concrete employed in Colombia, there are few research studies relating the material variability with the design of reinforced concrete structures and its response to external loads.

Consequently, $E$ and $f^{\text {' }} \mathrm{C}$ results were compiled for Bogota city only. The statistical sample includes test results developed on standard cylinders (150 mm diameter and $300 \mathrm{~mm}$ height) and the results for cores extracted from existing structures with varied diameters ranging from $50 \mathrm{~mm}$ to $76 \mathrm{~mm}$. Tests were done in accordance with the valid regulation NTC4025. Norma Técnica Colombiana (ICONTEC) (2005). Although the test technical regulations and the quality control procedures in Colombia recommend testing concrete at 28 days of age, the statistical sample employed by the current research includes $1.7 \%$ data of concretes assessed at an age inferior to 28 days. Most available results for elasticity modulus and compression strength were drawn from test reports developed between years 2005 and 2010, at the Test and Trial Laboratory of the Civil Engineering Department of the Pontificia Universidad Javieriana. It is worthwhile mentioning that the elasticity modulus test is included in the accreditation resolution of such Laboratory (09-Lab-023). Data base contains the results from 1566 trials for simultaneous determination of $f{ }^{~} \mathrm{C}$ and $\mathrm{E}$.

Figure $1 \mathrm{a}$ and $2 \mathrm{~b}$ present statistical data for $f^{\prime} \mathrm{C}$ and $\mathrm{E}$. such graphs also show the probability distribution function, which is mostly adjusted to the studied variables. For the determination of such distributions, the goodness-of-fit test by KolmogorovSmirnov was employed. Table 1 shows the main characteristics of goodness-of-fit function as well as the characteristics of the statistical sample.

Figure 1c shows the line of adjustment that relates the elasticity modulus (y-axis) with the square root of compression strength to the respective $R 2$, which is 0.46 . The lines defining the confidence interval (at 99\%) of the adjustment equation per least squares are simultaneously showed. It is quite obvious that in the zone showing fewer data, uncertainty significantly increases ( $f c 0.5<4$ and $f c 0.5>6$ ). Please note that the curve suggested by the regulation in force $(4700 * f$ 'c0.5) is quite higher than the adjustment equation suggested for Bogota's concretes observed in the figure, since the coefficient that multiplies $f$ 'c0.5 (4700 MPa) is 39\% lower than the value of the statistical regression (3386 MPa). 
As a cooperative activity, in the year 2008 the Test and Trial Laboratory participated in a teamwork study with some other 5 Laboratories in Bogota, organized by the Chair of ACI seccional Colombiana. From such data (only 17 records, from several laboratories), an average regression was calculated in $3365 * f$ 'c0.5, which is quite similar to the one obtained by the present research. Although the reference AIS. Asociación Colombiana de Ingeniería Sísmica (2010), is open to the option of using lower E values, it is only a suggestion that many estimators will never employ.

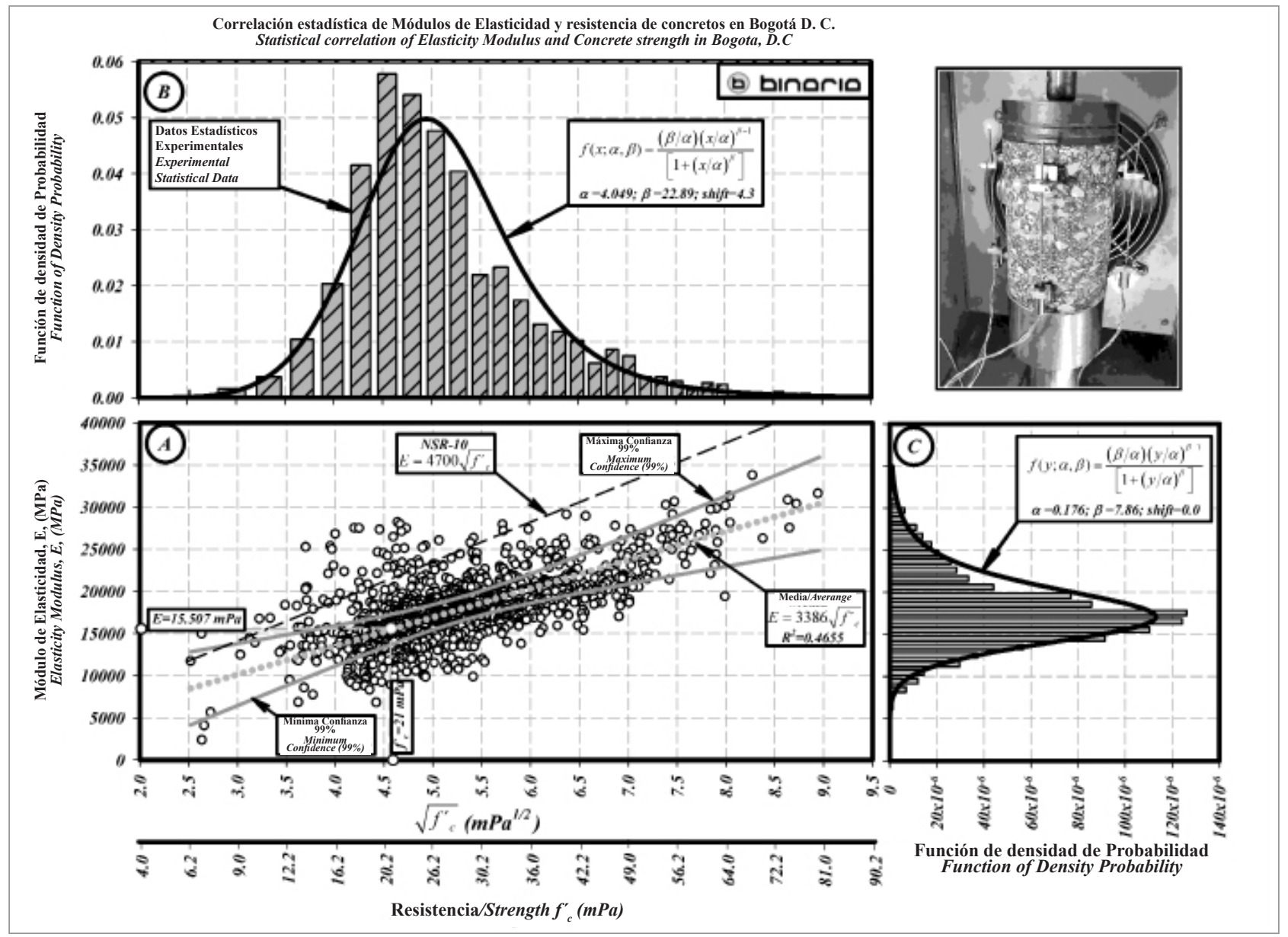

Figura 1. a) Distribución ajustada a los datos de $f^{`}{ }^{`} \mathrm{~b}$ b) Distribución ajustada a los datos de $E$ c) Regresión estadística para $E$ en función de $\left(f^{`}{ }^{`}\right)^{1 / 2}$ y $E$ Figure 1. a) Distribution adjusted to $f^{~}{ }^{\prime} \mathrm{C}$ data; $\left.\boldsymbol{b}\right)$ Distribution adjusted to $E$ data; $\boldsymbol{c}$ ) Statistical regression for $E$ in function of $\left(f^{~}{ }^{~} \mathrm{c}\right)^{1 / 2}$ and $E$

Tabla 1. Datos estadísticos de las variables $E$ y $f{ }^{`} \mathrm{C}$

Table 1. Statistical data of variables $E$ and $f^{\prime}$ '

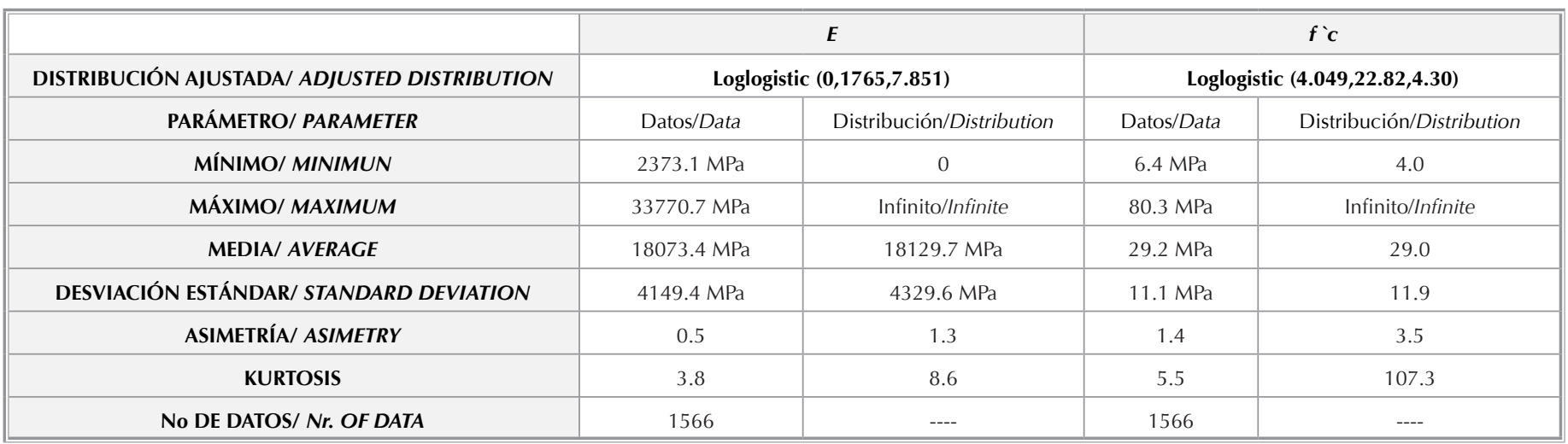




\section{Buildlings to be assessed}

Buildings designed by this research job, correspond to a typical structure plan studied during the 90's, so as to economically assess buildings designed under regulation AIS. Asociación Colombiana de Ingeniería Sísmica (1998), NSR98 (see Figure 2). Constant framing plan buildings under comparison are symmetrical; they show no irregularities either in height or in frame; they do not have height sections reductions, change of materials or their properties, or they do not have defective parts such as short columns or weak lower floors. They are great buildings, which are actually difficult to find. However, they were employed in this research for comparative and assessment purposes, but not to evaluate the effect of occasional defects on the structure behavior. A three-dimensional frame was developed and, the 3-axis frame was employed for the analysis in the current research job. Such frame has 5 floors, with spans of 9 meters and story height of 3 meters, as shown on Figure 3. The characteristics of materials employed were drawn from reference number AIS. Asociación

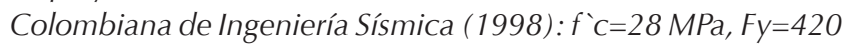
$\mathrm{MPa},=24870 \mathrm{MPa}$ and $\gamma_{\text {concrete }}=24 \mathrm{kN} / \mathrm{m}^{3}$. In order to conduct the analysis, two extreme cases showing local soil response in accordance with the reference FOPAE (Fondo de prevención y atención de emergencias) (2012), were considered, in the light of the new seismic micro-zoning in Bogota: Foothill B and Lake Plateau-500. Such areas spectrums are shown on Figure 4. Design dead load was $7.78 \mathrm{kN} / \mathrm{m}^{2}$, except for the deck designed with $3.34 \mathrm{kN} / \mathrm{m}^{2}$. Design live load was $1.8 \mathrm{kN} / \mathrm{m}^{2}$.

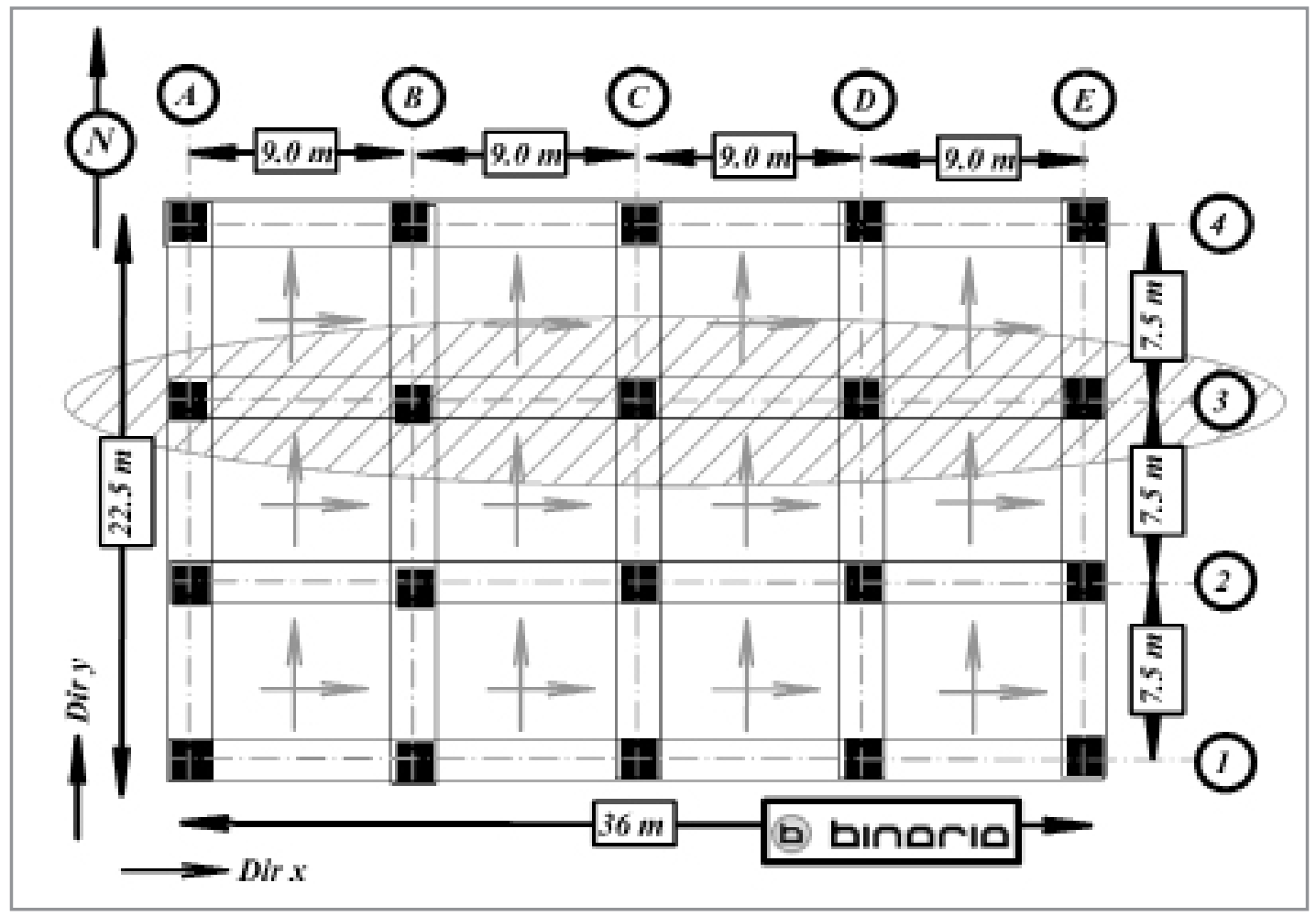

Figura 2. Planta Típica adaptada de García L. E. (1996)

Figure 2. Typical Framing plan adapted from García L. E. (1996) 


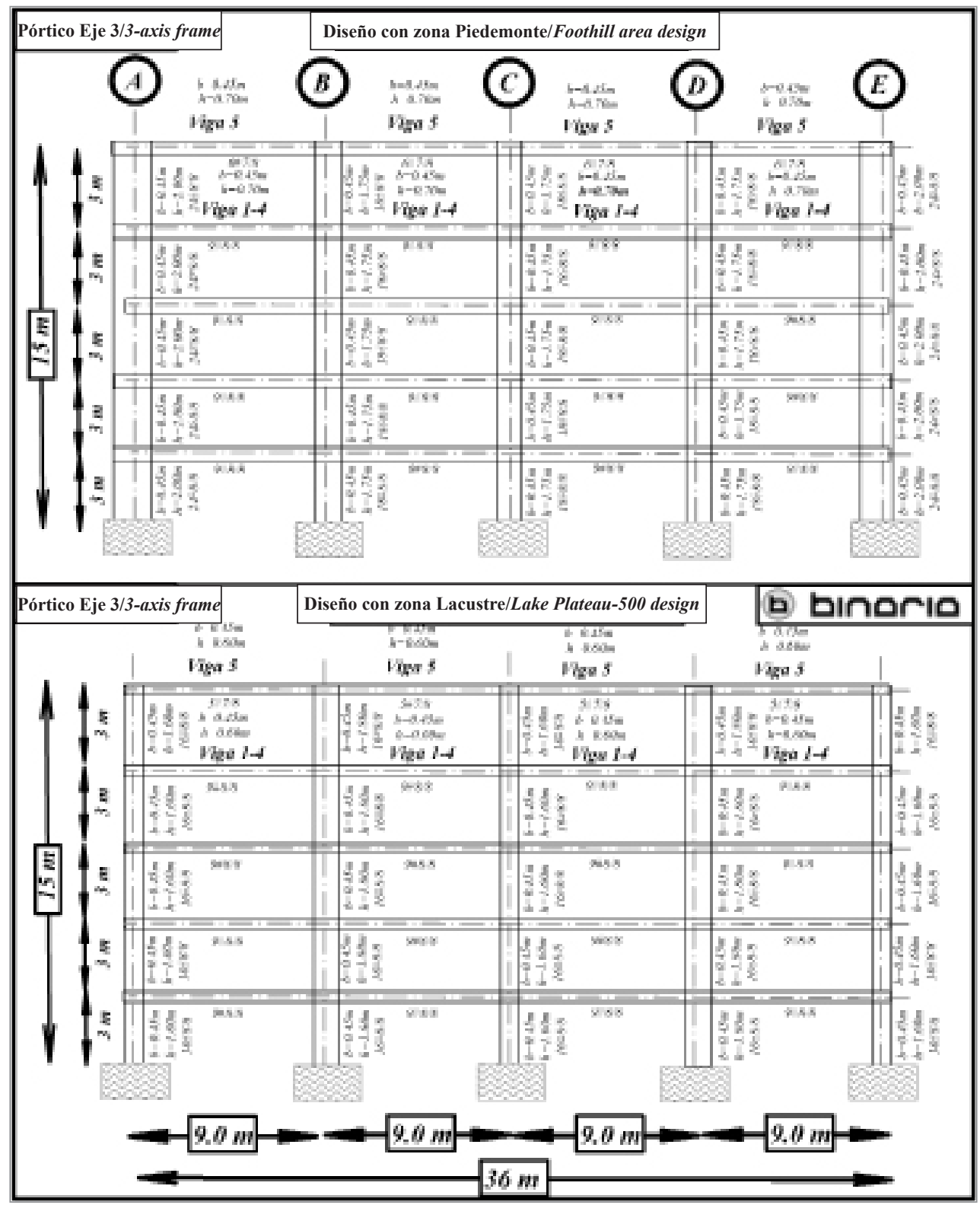

Figura 3. Pórtico eje 3 a) Diseño espectro Piedemonte B b)Diseño espectro Lacustre500

Figure 3. 3 axis frame a) Foothill spectrum design b) Lake Plateau-500 spectrum design

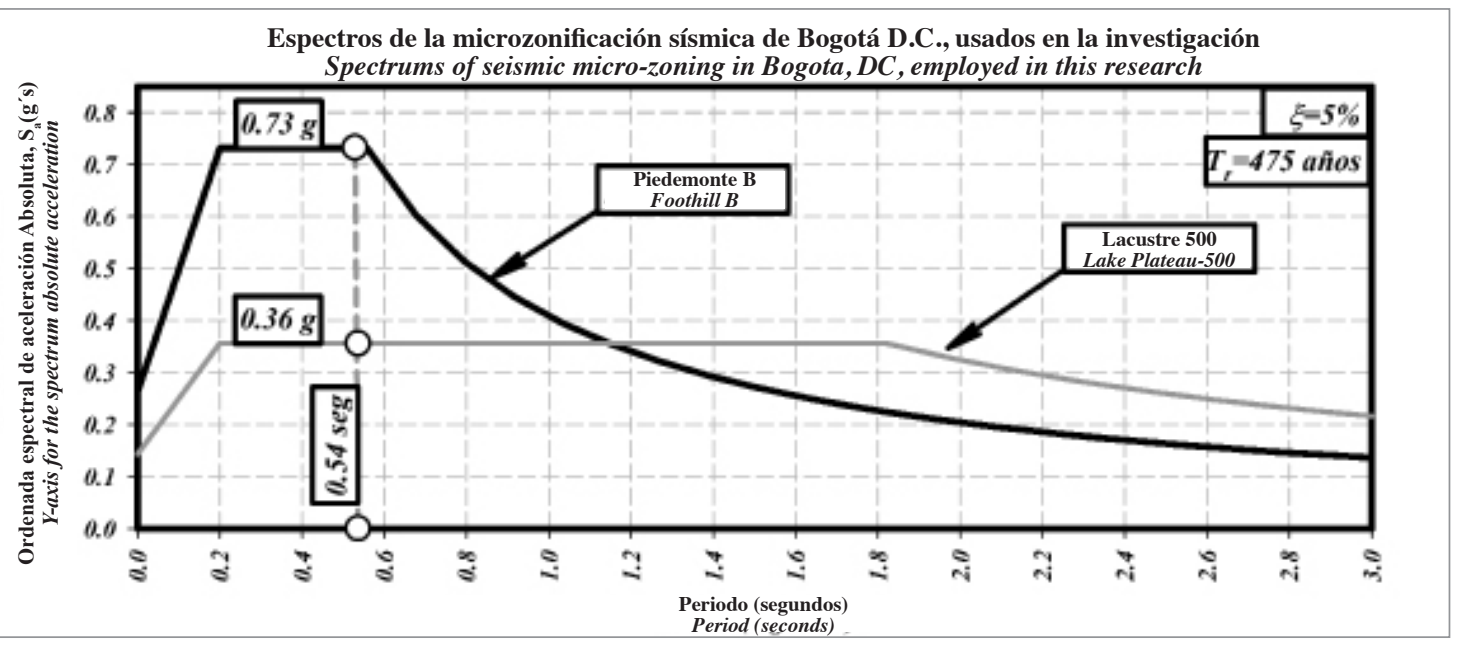

Figura 4. Espectros de diseño usados

Figure 4. Employed spectrum designs 
Based on such characteristics, structural elements dimensions were established (See Table 2 and Figure 3), which ensure the fulfillment of strength and flexibility requirements by NSR-10 (design of interstory deformation < 1\%). Design was developed based on the Equivalent Horizontal Force. Designed interstory deformations were close to $0.9 \%$.

Tabla 2. Dimensiones de elementos estructurales

Table 2. Structural elements dimensions

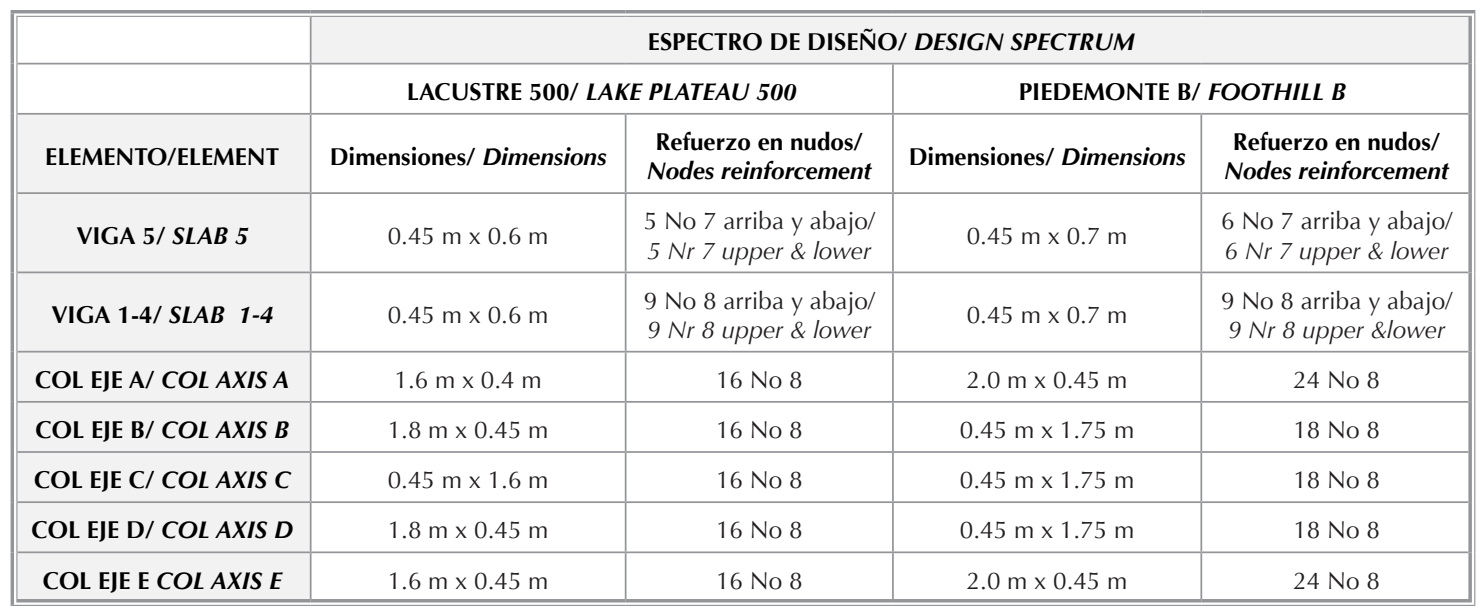

\section{Numerical simulations}

After achieving the characteristics of concrete mechanical variations, 1500 random values were created for concrete compression strength $\left(f^{\prime} \mathrm{C}\right)$. Such values were employed for the regression shown on Figure 1C, so as to determine 1500 concrete elasticity modulus values. Probability distributions of these two variables ( $f$ ' $c$ and $E$ ) correspond to LogLogistic. However, a Regular distribution was employed to create the random values for the two variables. According to González V., Botero J. C., Rochel R., Vidal J., Álvalrez M. (2005), the values representing the tension-deformation curve are considered as steady variables, therefore, it is possible to find out an adjustment approximation to a regular distribution. On the other hand, according to references Mays L, Tung Y. (1992); Ang A. H.-S. (1973) and Sánchez Mauricio (2004), it is possible develop a simulation and reliability analysis, even for probability distribution functions, which are different to the regular one, but achieving satisfactory results.

Each one of these 1500 elasticity modulus values were related to the two models of buildings designed with Foothill B and Lake Plateau 500 spectrums, so as to develop simulations to achieve the story maximum elastic deformation. The analyses of live loads and dead loads were not included, since they have no significant effect on deformation. The interstory elastic deformation was obtained for two loads types: spectral modal elastic analysis (AME) and an analysis based on the equivalent horizontal force (FHE) employed for the design of each building, for a total of 6000 simulations (1500 per building and per type of analysis). 
In order to conduct these simulations, an interface built in the SAP2000 (CSI. Computers and Structures Inc., 2007) software was employed, in order to operate most commands by means of the Visual Basic application by Excel. Afterwards a program was created to replace the elasticity modulus and the ${ }^{\prime}{ }^{\prime} \mathrm{C}$ values in the framing plane developed by SAP200 and results were stored by using Excel. The statistics and frequency diagrams of maximum interstory deformations were assessed by means of statistic tools, so as to later adjust the most adequate probability distribution functions, just as it was done with concrete mechanical properties.

In order to establish if the statistical sample including 1500 values was reliable for the calculation of the four analyzed interstory deformations (two design spectrums and two analysis types); the Figure 5 presents the evolution of the interstory elastic deformation for different simulations, where it is quite clear that from 200 simulations on, the average values of calculated deformations are kept quite steady. Interstory deformations of the two designed buildings and of the two analyses have a similar behavior, since the same $1500 \mathrm{f}^{\text {' } \mathrm{C} \text { and }}$ E values were assessed for the buildings. On the other hand, standard deviation of the analyzed samples had a similar behavior.

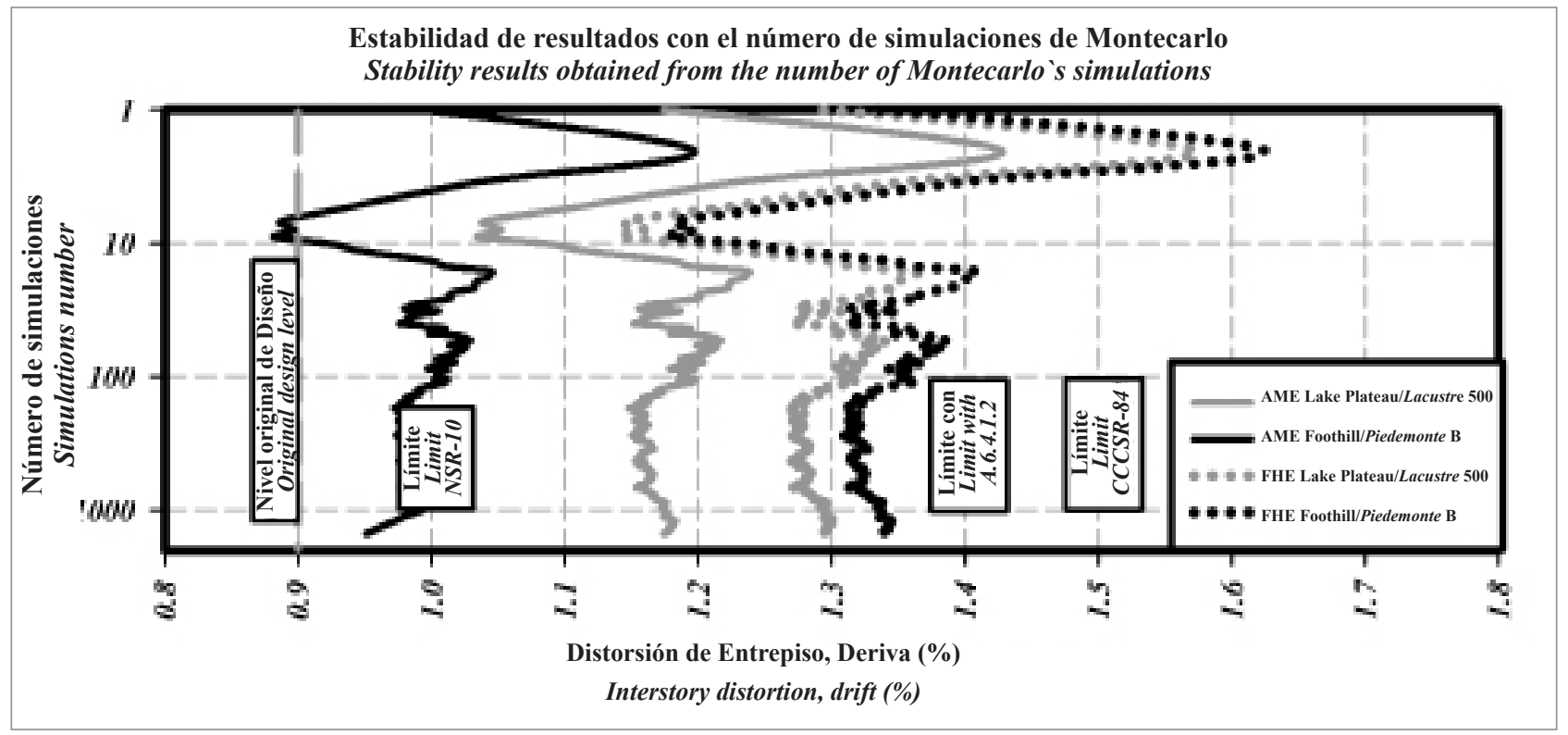

Figura 5. Comportamiento de la deformación de entrepiso en función del número de simulaciones

Figure 5. Behavior of interstory deformation as a function of the number of simulations

Figure 6 shows the results of simulations carried out for both buildings (Lake Plateau 500 design and Foothill B design), which were subject to derivative loads FHE and AME. Table 3 shows the sample statistical parameters and the probability distribution functions adjusted in accordance with the goodness-of-fit test by Kolmogorov-Smirnov. At the same time, each case shows the probability that the statistical sample of interstory deformations be lower than $1 \%$ limit (buildings showing an adequate behavior). 
As expected, the calculated average deformations, for each assessed case, are higher than designed interstory deformation: $0.9 \%$ and $0.91 \%$. Similarly, calculated deformations by means of FHE are higher than the ones calculated by means of AME, for both cases. This is so because AME deformations take into account the periods of time, vibration modes and modal participation factors contrarily to FHE analysis. It is worthwhile mentioning that the probability distribution function of buildings designed by means of Foothill B spectrum for AME shows a different behavior compared to the other three ones. Therefore, the changes of associated periods together with E changes make the spectral acceleration vary between the steady spectral acceleration zone and the zone where spectral acceleration decreases in the course of time. In the building AME designed in Lake Plateau 500 area, the steady spectral acceleration runs up to periods of 2 seconds, keeping the applied strength steady in the same way as FHE analyses do.

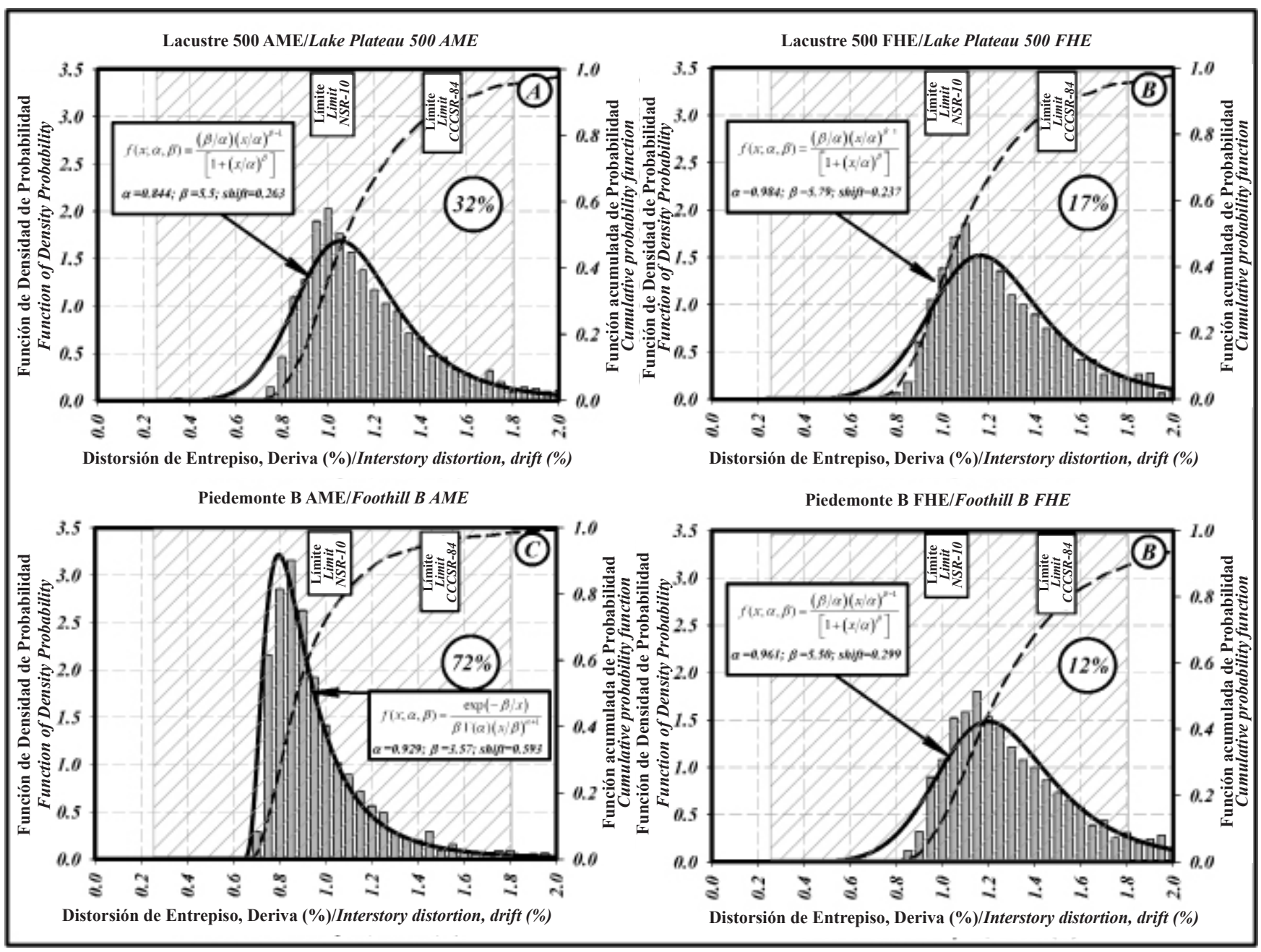

Figura 6. Análisis estadísticos y funciones de distribución de probabilidad ajustada para la deformación de entrepiso de los dos edificios diseñados (con Piedemonte B y con Lacustre 500) y para análisis modal espectral y para fuerza horizontal equivalente

Figure 6. Statistical analysis and adjusted probability distribution functions for interstory deformation on both designed buildings (Foothill B and Lake Plateau 500); spectral mode analysis and equivalent horizontal force 
When averaging interstory deformation obtained from FHE and AME in both buildings, it is quite clear that they exceed in $31 \%$ the design deformation, which was $0.9 \%$ approximately. Consequently, in the worst of the cases only the $12 \%$ of the statistical sample (FHE and Foothill B designed building) meet a maximum interstory deformation of $1 \%$. Above is consistent with the asymmetry coefficient in all cases, indicating that distribution functions tend to achieve values higher than the limit established in 1\%.

Similarly, confidence intervals associated with $\mu+/-2 \sigma$ (95\% confidence approximately) show interstory deformation values that in many cases can achieve up to $2 \%$. These values double the design interstory deformation, which means that buildings designed in accordance with NSR-10 will surely undergo higher damage levels than the ones designed as per NSR-98. In the same way, according to push-over non-linear analyses by Borrero (2011) regarding deformations higher than $1.4 \%$, diverse structural elements might have hinge breakdowns avoiding immediate occupancy and compromising life safety limits.

Tabla 3. Parámetros estadísticos de las deformaciones elásticas de entrepiso estimadas, tanto para la muestra como para las funciones de ajuste Table 3. Statistical parameters of calculated elastic interstory deformations, for the sample as well as for adjustment functions

\begin{tabular}{|c|c|c|c|c|c|c|}
\hline & & & \multicolumn{4}{|c|}{ TIPO DE ANÁLISIS/ TYPE OF ANALYSIS } \\
\hline & & & \multicolumn{2}{|c|}{$\begin{array}{l}\text { MODAL ELÁSTICO ESPECTRAL/SPECTRAL } \\
\text { ELASTIC MODAL }\end{array}$} & \multicolumn{2}{|c|}{$\begin{array}{l}\text { FUERZA HORIZONTAL EQUIVALENTE/ EQUIVA- } \\
\text { LENT HORIZONTAL FORCE }\end{array}$} \\
\hline \multirow{8}{*}{ 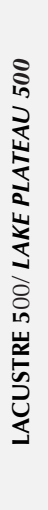 } & \multirow{8}{*}{ 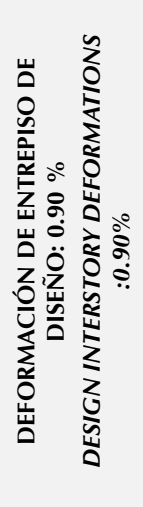 } & PARÁMETRO/ PARAMETER & $\begin{array}{l}\text { DATOS ESTADÍSTICOS/ } \\
\text { STATISTICAL DATA }\end{array}$ & $\begin{array}{l}\text { DISTRIBUCIÓN } \\
\text { DISTRIBUTION }\end{array}$ & $\begin{array}{l}\text { DATOS ESTADÍSTICOS/ } \\
\text { STATISTICAL DATA }\end{array}$ & $\begin{array}{l}\text { DISTRIBUCIÓN } \\
\text { DISTRIBUTION }\end{array}$ \\
\hline & & $\begin{array}{l}\text { DISTRIBUCIÓN AJUSTADA } \\
\text { ADJUSTED DISTRIBUTION }\end{array}$ & \multicolumn{2}{|c|}{ Loglogistic $(0.263,0.844,5.50)$} & \multicolumn{2}{|c|}{ Loglogistic $(0.237,0.984,5.796)$} \\
\hline & & MÍNIMO/ MINIMUM (\%) & 0.32 & 0.26 & 0.30 & 0.24 \\
\hline & & MÁXIMO/ MAXIMUM (\%) & 2.75 & Infinito & 2.95 & Infinito \\
\hline & & Media $\mathrm{m} /$ Average $m(\%)$ & 1.17 & 1.16 & 1.29 & 1.27 \\
\hline & & $\begin{array}{l}\text { Coeficiente de Variación } \\
\text { Variation coefficient }\end{array}$ & $28 \%$ & $27 \%$ & $29 \%$ & $27 \%$ \\
\hline & & Asimetría/ Asymmetry & 1.62 & 2.09 & 1.58 & 1.92 \\
\hline & & $m+/-2 s(\%)$ & 0.51 a 1.83 & 1.80 & 0.55 a 2.03 & 1.95 \\
\hline \multirow{8}{*}{ 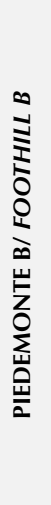 } & \multirow{8}{*}{ 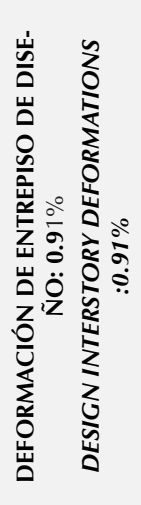 } & PARÁMETRO/ PARAMETER & $\begin{array}{l}\text { DATOS ESTADÍSTICOS/ } \\
\text { STATISTICAL DATA }\end{array}$ & $\begin{array}{l}\text { DISTRIBUCIÓN } \\
\text { DISTRIBUTION }\end{array}$ & $\begin{array}{l}\text { DATOS ESTADÍSTICOS/ } \\
\text { STATISTICAL DATA }\end{array}$ & $\begin{array}{l}\text { DISTRIBUCIÓN } \\
\text { DISTRIBUTION }\end{array}$ \\
\hline & & $\begin{array}{l}\text { DISTRIBUCIÓN AJUSTADA } \\
\text { ADJUSTED DISTRIBUTION }\end{array}$ & \multicolumn{2}{|c|}{ Pearson5 $(3.57,0.929$, Shift(0.593)) } & \multicolumn{2}{|c|}{ Loglogistic $(0.299,0.961,5.50)$} \\
\hline & & MÍNIMO/ MINIMUM (\%) & 0.67 & 0.59 & 0.36 & 0.30 \\
\hline & & MÁXIMO/ MAXIMUM (\%) & 2.20 & Infinito & 3.13 & Infinito \\
\hline & & Media/ Average (\%) & 0.95 & 0.96 & 1.34 & 1.31 \\
\hline & & $\begin{array}{l}\text { Coeficiente de Variación } \\
\text { Variation coefficient }\end{array}$ & $25 \%$ & $30 \%$ & $28 \%$ & $27 \%$ \\
\hline & & Asimetría/ Asymmetry & 2.07 & 8.81 & 1.62 & 2.09 \\
\hline & & $m+/-2 s$ & 0.47 a 1.43 & 1.54 & 0.58 a 2.10 & 2.03 \\
\hline
\end{tabular}


Figure 7 shows the limit exceeding probabilities associated to the probability distribution functions of Figure 6 . In accordance with such figures, in three of the four analyzed cases there is a probability, of at least $67 \%$, that buildings designed as per NSR-10 in Bogota will have an interstory deformation higher than $1 \%$ for seismic design.

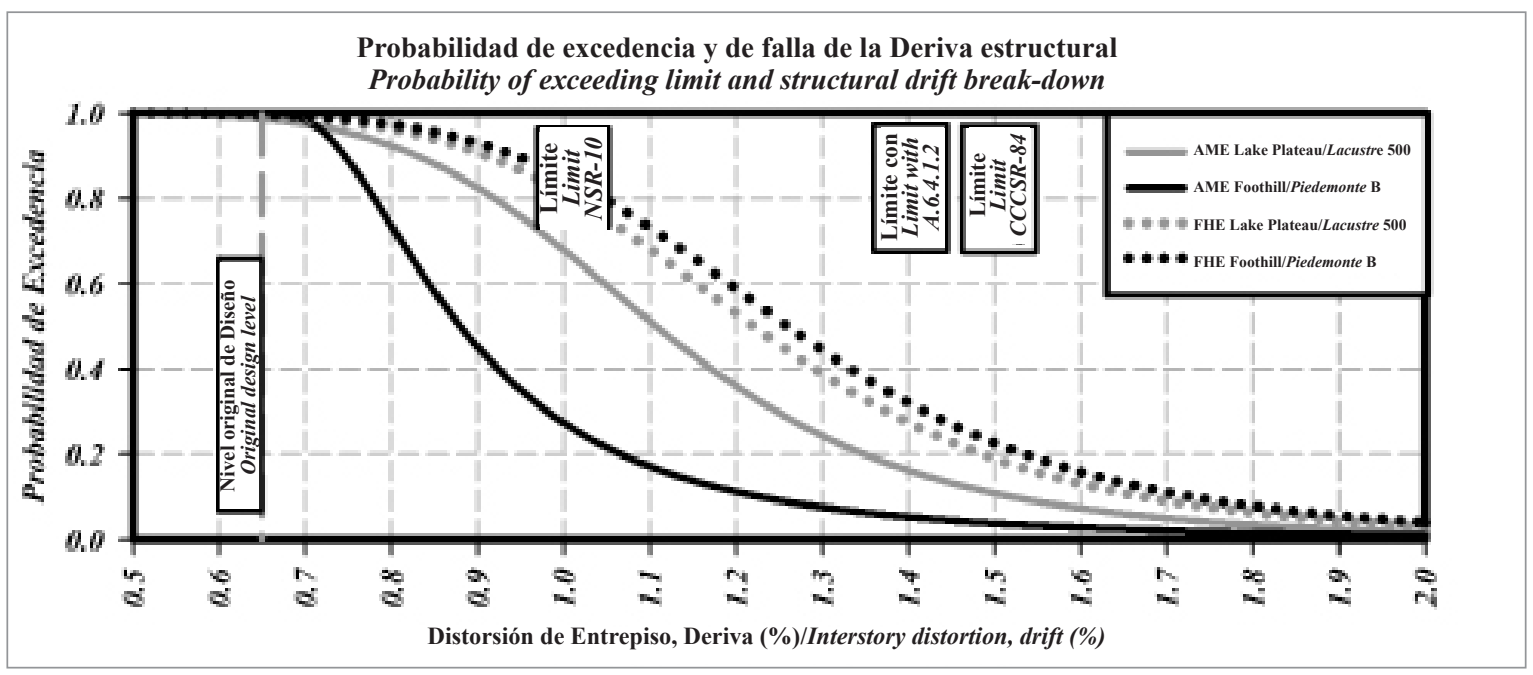

Figura 7. Probabilidad de excedencia de la deformación de entrepiso estructural

Figure 7. Exceeding limit probability for structural interstory deformation

Such data are the direct consequence of equation $E=4700 \sqrt{ } f^{\prime} \mathrm{C}$ (included in the regulation NSR-10) used to estimate the concrete elasticity modulus for buildings constructed in Bogota, which clearly leads to increase seismic damage risk in buildings that are being constructed since January 2011.

\section{Conclusions and recommendations}

In accordance with the statistical sample, compiled by the authors for concrete in Bogota, the compression resistance values at 28 days, $f^{\prime} \mathrm{C}$, vary between 80.3 MPa and 6.4 MPa. Therefore, considering the present statistical analysis, the assessed sample has an average of 29.2 MPa and a standard deviation of 11.1 MPa. Hence the most adequate distribution is LogLogistic.

The sample's elasticity modulus values, $E$, vary from $33770 \mathrm{MPa}$ to $2373 \mathrm{MPa}$. The sample's average is $18073 \mathrm{MPa}$ and standard deviation is $4149 \mathrm{MPa}$. Similarly to the concrete compression strength, the most adequate distribution is LogLogistic.

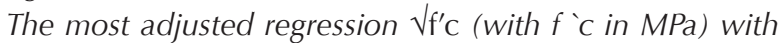
$E$, in the light of laboratory test results is $E=3386 \sqrt{ } \mathrm{f}^{\prime} \mathrm{C}$. Such estimation is 39\% lower than the specification suggested by NSE-10, which proposes using an elasticity modulus $E=4700 \sqrt{ } f^{\prime} \mathrm{C}$.

Counting with a confidence level of $95 \%$, it can be stated that elastic interstory deformation for a frame designed from materials in Bogota, using the design spectrum Foothill B, it can achieve values between $0.47 \%$ and $2.1 \%$, considering that the frame was designed for a deformation of $0.91 \%$. 
The distribution that best fitted statistical data, for maximum interstory deformations, showed an asymmetry towards deformation values higher than $1 \%$.

Counting with a confidence level of $95 \%$, it can be stated that elastic interstory deformation for a frame designed from materials in Bogota, using the design spectrum Lake Plateau 500, it can achieve values between $0.51 \%$ and $2.03 \%$, considering that the frame was designed for a deformation of $0.90 \%$.

In the worst analyzed case, the average maximum interstory deformation achieved by frames was $147 \%$; and the average design deformation was $131 \%$.

In the light of statistical results, 67 out of 100 five-story buildings built in Bogota under regulation NSR-10 would have interstory deformation levels higher than 1\%, as they are subject to seismic strengths calculated by means of the new micro-zoning plan.

\section{Acknowlegements}

Authors wish to thank the Vice Rectorate of Academic Affairs, the Engineering Faculty and the Tests Laboratory of the Pontificia Universidad Javieriana for providing human resources, the required information and equipment to develop the present research study, which results are hereby presented. At the same time, authors wish to thank the Engineer Mauricio Gallego for his outstanding contribution to technical-scientific discussions held during the results analysis stage.

\section{Referencias/References}

ACI (Seccional colombiana) (2002), Informe final de la consolidación de resultados Interlaboratorios de Módulo Elástico - ASTM C 469-02.

AIS (Asociación Colombiana de Ingeniería Sísmica) (2010), Normas Colombianas de Diseño y Construcción Sismo Resistente (NSR-10). Bogotá Colombia.

AIS (Asociación Colombiana de Ingeniería Sísmica) (1998), Normas Colombianas de Diseño y Construcción Sismo Resistente (NSR-98). Bogotá Colombia.

Ang A.H.-S. (1973), Structural Risk Analysis and Reliability-Based Design. Journal of Structural Engineering Division, 99, 1973, Pag 20-35

CSI (Computers and Structures Inc). (2007), SAP 2000. Static and Dynamic Finite Element Analysis of Structures, Nonlinear.

FOPAE (Fondo de prevención y atención de emergencias) (2010), Zonificación de la respuesta sísmica de Bogotá para el diseño sismo resistente de edificaciones. Informe final. Bogotá.

García L. E. (1996), Economic considerations of displacement-based seismic design of structural concrete buildings. Structural Engineering International Vol $6 \mathrm{n}^{\circ} 4,1669$.IABSE. Zurich, Suiza.

Gallego M. \& Sarria A. (2006), El concreto y los terremotos. Conceptos, comportamiento, patología y rehabilitación. Asociación Colombiana de Productores de Concreto (Asocreto), Instituto del Concreto.

González V., Botero J. C., Rochel R., Vidal J., Álvalrez M. (2005), Propiedades mecánicas del acero de refuerzo utilizado en Colombia. Revista Ingeniería y Ciencia. Volumen 1. Número 1. Pp $67-76$.

Mays. L, Tung Y. (1992), Hydrosystems Engineering and Management. McGraw Hill Series in Water Resources and Environmental Engineering. New York: Mc Graw Hill

Muñoz E., Ruiz D., Prieto J. (2005), Estimación de la confiabilidad estructural de una edificación indispensable mediante análisis no lineales estáticos de pushover. Congreso Chileno de Sismología e Ingeniería Antisísmica, IX Jornadas. Artículo Nº A10-13. Concepción, Chile.

NTC4025. Norma Técnica Colombiana (ICONTEC) (2005), Concretos. Método de ensayo para determinación del módulo de elasticidad estático y la relación de Poisson en concreto a la compresión.

Prieto J., Muñoz E., Ruiz D., Ramos A. (2005), Estimación de la incertidumbre aleatoria del punto de desempeño de una edificación esencial. Congreso Chileno de Sismología e Ingeniería Antisísmica, IX Jornadas. Artículo Nº A04-02. Concepción, Chile.

Ruiz D., Vacca H. y León M. (2007), Propuesta de modificación de la ecuación para la estimación del módulo de elasticidad del concreto en función de la resistencia a la compresión para Bogotá. Revista de la Escuela Colombiana de Ingeniería №67 Julio - Septiembre. pp 7-15.

Sánchez Mauricio (2004), Introducción a la confiabilidad y evaluación de riesgos. Facultad de Ingeniería, Universidad de los Andes, Ediciones Uniandes. Bogotá, Colombia. 